DOI 10.15826/qr.2015.3.122

УДК 811.161.1'373+316.77:339

Наталия Купина

РУССКАЯ РЕЧЬ И РЫНОК: ТРАДИЦИИ И ИННОВАЦИИ В ДЕЛОВОМ И ПОВСЕДНЕВНОМ ОБЩЕНИИ ${ }^{1}$

Рец. на кн.: Ратмайр, Р. Русская речь и рынок : Традиции и инновации в деловом и повседневном общении / Ренате Ратмайр. - М. : Языки славянской культуры, 2013. - 456 c. (Studia philologica).

Natalia Kupina

\title{
RUSSIAN SPEECH AND MARKET: TRADITIONS AND INNOVATIONS IN BUSINESS AND EVERYDAY COMMUNICATION
}

Review of Ratmajr, Renate. (2013). Russkaya rech'i ry'nok:

Tradicii i innovacii $v$ delovom $i$ povsednevnom obshhenii [Russian Speech and Market: Traditions and Innovation in Business and Everyday Communication]. 456 p. Moscow, Yazy'ki Slavyanskoj Kul'tury'. (Studia philologica).

In her review of Russian Speech and Market: Traditions and Innovations in Business and Everyday Communication (Moscow, Yazy'ki Slavyanskoj Kul'tury', 2013) by Austrian Slavicist Renate Rathmayr, the author analyzes research results relating to shifts that took place in Russian business and everyday communication under the influence of global socio-cultural processes. The reviewer focuses her attention on the theoretical propositions formulated by $\mathrm{R}$. Rathmayr based on the contrasting approach in each of the three parts of the book: "Vocabulary and Concepts", "Pragmatics" and "Russian Communication Style". The article proposes a critical assessment of the author's interpretation of

${ }^{1}$ Работа выполнена при финансовой поддержке РГНФ (грант 15-04-00239 а «Национальные базовые ценности и их отражение в коммуникативном пространстве провинциального города: традиции и динамика»).

(c) Купина Н., 2015

Quaestio Rossica • 2015 • №3, p. 273-279 
the reflection of time in the language of the totalitarian era. The reviewer states that the material and observations systematized by R. Rathmayr, which involve the existence of speech and its generic determination, enrich modern linguistic knowledge on the nature and character of linguistic processes and extend the existing idea of the phenomenon of Russianness.

Keywords: Russian; speech communication; market economy; innovations; values; socio-centrism; European cultural context.

В рецензии на книгу австрийского слависта Ренате Ратмайр «Русская речь и рынок: Традиции и инновации в деловом и повседневном общении» (М.: Языки славянской культуры, 2013) анализируются научные результаты исследования сдвигов, которые происходили на протяжении 25 лет в русской деловой и обыденной коммуникации под влиянием глобальных социокультурных процессов. Особое внимание рецензент уделяет теоретическим положениям, сформулированным Р. Ратмайр на основе контрастивного подхода в каждом из трех разделов книги: «Лексика и концепты», «Прагматика», «Русский стиль общения». Критически осмысляется принятая автором монографии трактовка отражения времени в языке тоталитарной эпохи. Отмечается, что систематизированные Р. Ратмайр материалы и наблюдения, охватывающие речевое существование в его жанровой определенности, обогащают данные современной лингвистической науки о природе и характере языковых процессов, углубляют сложившиеся представления о феномене русскости.

Ключевые слова: русский; речевая коммуникация; рыночная экономика; инновации; ценности; социоцентричность; европейский культурный контекст.

В книге Р. Ратмайр представлены наблюдения и обобщения, связанные со сдвигами в русской речевой коммуникации. Язы-

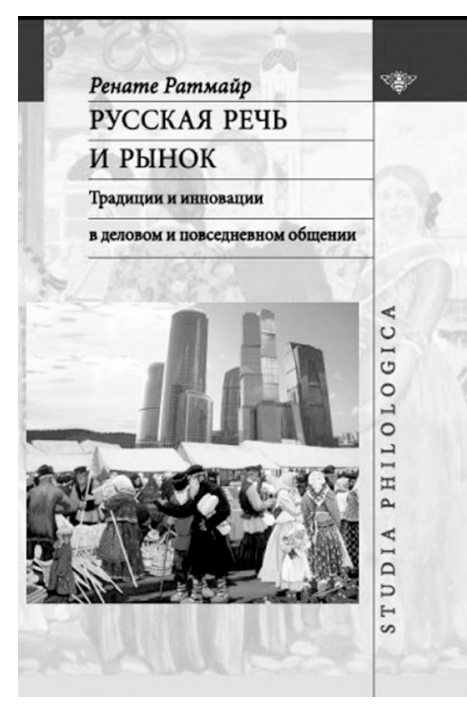
ковое существование - от горбачевской перестройки до наших дней рассматривается в контексте глобальных социокультурных изменений. Контрастивный подход, сопровождающий рассуждения автора о ментально-ценностных особенностях русского языкового сознания и речевого поведения, позволяет по-новому интерпретировать природу оппозиции Россия - Запад, зафиксировать системно-языковые и речеповеденческие инновации, в том числе обусловленные переходом от плановой экономики к экономике рыночной, выявить лингвоаксиологические последствия такого перехода. 
Объект исследования - расположенные на шкале времени тексты СМИ, тексты политических выступлений, инструкций, объявлений, меняющийся язык улицы, а также записи устных непринужденных диалогов в разных ситуациях русского коммуникативного речевого взаимодействия, записи образцов письменной и устной деловой речи, фокусированные интервью, результаты соцопросов. Репрезентативный языковой материал обеспечивает достоверность представленных автором концептуальных выводов.

Структура монографии, состоящей из введения, трех основных частей и заключения, мотивирована дифференциацией исследовательских подходов: подход лингвокогнитивный (часть 1); прагматический (часть 2); культуролого-стилистический (часть 3). Процедура анализа во всех случаях остается социоцентрической, комплексной, включающей количественные методы обработки полученных данных. Социолингвистическая доминанта сближает исследование Р. Ратмайр с трудами российских ученых [Русский язык конца XX столетия; Русский язык сегодня; Русский язык в многоречном социокультурном пространстве; Современный русский язык; и др.].

В разделе «Лексика и концепты» последовательно рассматриваются произошедшие под влиянием политических событий 1980 - начала 1990-х гг. языковые изменения и сдвиги в картине мира носителей русского языка и культуры. Анализ проводится в проекции на ближнюю ретроспекцию - советский период функционирования языка. Убедительно демонстрируется влияние горбачевских политических реформ, не предполагавших разрушения фундаментальных принципов социализма, на процессы либерализации языка, текстопорождения, раскрепощения речевой индивидуальности, обновления способов аргументации. Внимание автора привлекает перестройка жанрового репертуара текстов СМИ и текстов политической, в том числе парламентской, речи и связанная с этой перестройкой возможность множественных толкований одного события. Описывается интенсивное расшатывание идеологических стандартов, бинарных идеологических примитивов, конкретизирующих в языке советской эпохи оппозицию свое - чужое.

Нельзя, однако, признать объективной интерпретируемую как характерную для тоталитарного языка схему «хмурое настоящее светлое будущее» [Ратмайр, с. 48]. Темпоральный схематизм в языке советской эпохи сочетался с идеологическим оптимизмом, исключавшим «очернение действительности». Разрабатывались экспрессивные стандарты, поддерживающие мифологическое восприятие текущего момента. Яркий пример - устойчивое сочетание прекрасное настоящее, обозначавшее коллективное отношение «к социалистической действительности, жизни в советское время» [Мокиенко, Никитина, c. 360]. При этом «светлое коммунистическое будущее» манипулятивно включалось в настоящее [см.: Купина, с. 70-74]. 
В контексте текущих событий Р. Ратмайр исследует изменения в лексической системе языка, сопровождающиеся возвращением в речевой оборот дореволюционной лексики, лексики православия, выявляет направления переоценок, избавление лексической семантики от искусственных идеологических добавок. Акцентируется эвристичность метаязыковых комментариев, указывающих на восприятие носителем языка лексических новаций в их связях и отношениях с концептуально значимыми смыслами [ср.: Вепрева, с. 27-117]. Изменения оценочного взгляда на мир емко представлены на материале функционирования в речи лексемы нормальный.

Особый интерес для русистики представляют обобщающие положения, сформулированные на основе изучения вызванного экспансией англицизмов обновления определенных тематических сфер (политики, экономики, информационных технологий, массового потребления, спорта и др.). Отмечены включенные в европейский лингвокультурный контекст формы языкового сопротивления заимствованиям. Системно прослеживаются когнитивные следствия конфликта между социалистической идеологией и рыночной экономикой. В соотношении с традиционной системой нематериальных базовых ценностей выявляются когнитивные признаки концептов «качество жизни», «деньги».

В разделе «Прагматика» для специального рассмотрения выделена обнаруживающая себя в коммуникативном взаимодействии лингвокультурная специфика русской вежливости: описываются позитивные фатические стратегии и стратегии негативные, анализируются стереотипы формальной и неформальной вежливости в их проекции на речевые позиции адресанта и адресата. Ценные выводы охватывают сферу делового общения. Отмечена роль частиц в жанре переговоров, выявлен функциональный диапазон частицы просто, способствующий формированию эффекта вежливости, а также коррекции образа говорящего.

Мена речевых формул вежливости, которые реализуются в разных сферах коммуникации, побуждает Р. Ратмайр сформулировать проблемный вопрос: “"Новая русская вежливость" - преходящая мода делового этикета или коренное прагматическое изменение?» [Ратмайр, с. 190]. Материалы интервью и соцопросов позволяют автору установить связь между «новой вежливостью» и рыночной экономикой, которая обусловливает процесс повышения вежливости. Характеризуя русскую культуру как «культуру говорения», автор обращает внимание на возможное внутрикультурное восприятие повышенной вежливости (в отличие от искренности) как инструмента достижения прагматической сверхзадачи.

Практической полезностью обладают материалы и наблюдения, характеризующие русскую манеру делового общения со «своими» и «чужими», мотивированный выбор прагматически ориентированных способов аргументации. Неожиданным является подкреплен- 
ный языковыми иллюстрациями вывод о преобладании в деловой русской речи рациональных, а не эмоциональных аргументов, в том числе в ситуации несогласия. Представленные в монографии материалы и выводы окажутся полезными для составления рекомендаций, направленных на формирование механизмов толерантной деловой коммуникации.

Включение в исследовательский материал расшифрованных записей собеседований при приеме на работу дает возможность охарактеризовать лингвокультурные типажи интервьюеров и интервьюируемых. Классификация реплик и двуреплик не только вскрывает причины коммуникативных неудач, но и способствует выявлению принципов эффективной внутрикультурной деловой коммуникации.

Ментальная ценностная константа, обнаруженная в процессе анализа корпуса текстов-собеседований, - предпочтение соискателями «перспективы $\boldsymbol{м ы » ~ « п е р с п е к т и в е ~ я » . ~ В м е с т е ~ с ~ т е м ~ у б е д и т е л ь - ~}$ но доказано, что актуальный жанр собеседований испытывает направленное влияние западных моделей, стимулирующих конфликт с русскостью.

В разделе «Русский стиль общения» углубленно исследуются проявления феномена русскости в условиях рыночной экономики. Приметы русского стиля (многословие, смешение личного и профессионального, открытость, искренность), как показывают записи собеседований, «прорываются» вопреки изученным инструкциям. Наблюдается неожиданная мена ролей: например, соискатель советует интервьюеру, как следует руководить предприятием. Установлено, что формы речевого поведения, выходящие за границы дозволенного, оказываются очевидными в жанре самопрезентации.

В монографии обозначены особенности формирования и реализации «менеджерского» стиля, выявлена зависимость конвенционального речевого поведения от иерархии ролей. Корпоративная культура сегодня характеризуется специфическими принципами отбора и реализации ключевых слов и формульных выражений, о чем свидетельствуют приведенные автором монографии сведения о частотности речевых единиц. Параллельно интерпретируются формы проявления конфликта между русским стилем общения и правилами корпоративного речевого поведения, прогнозируются направления развития менеджерских речевых практик в русском деловом мире.

Развернуто представлен межкультурный аспект исследования, предполагающий интерпретацию коммуникативного взаимодействия в границах контрастивной прагматики. Обнаружены наведенные рыночной экономикой сдвиги в речевой ткани утилитарных текстов, функционирующих в открытом публичном пространстве, и текстов, ориентированных на российского потребителя (инструкции по эксплуатации аппаратов и приборов; речевые отличия от немецких жанровых аналогов). 
Нельзя не отметить наблюдения и обобщения автора, являющиеся итогом глубокого анализа осуществляемых в течение шестнадцати лет записей российско-австрийских переговоров о сотрудничестве университетов. Контрастивный подход позволил установить влияние культурных, собственно языковых и стилистических различий на ход и результаты переговоров, выявить принципы коммуникативной кооперации и причины разногласий, зафиксировать позитивные изменения, которые обусловливают нейтрализацию очагов напряжения, способствуют сближению коммуникативных стратегий и тактик участников переговорного процесса.

Предложенное Ренате Ратмайр оригинальное исследование динамики русского речевого существования в его жанровой определенности обогащает данные современной лингвистической науки о характере языковых изменений, способствует углубленному осмыслению феномена русскости.

\section{Список литературы}

Benрева И. Т. Языковая рефлексия в постсоветскую эпоху. Екатеринбург : Изд-во Урал. ун-та, 2012. 380 с.

Купина Н. А. Тоталитарный язык : Словарь и речевые реакции. 2-е изд., испр. и доп. Екатеринбург : Изд-во Урал. ун-та, 2015. 186 с.

Мокиенко В. М., Никитина Т. Г. Толковый словарь языка Совдепии. СПб. : ФолиоПресс, 1998. 704 c.

Ратмайр, $P$. Русская речь и рынок : Традиции и инновации в деловом и повседневном общении. М. : Языки славянской культуры, 2013. 456 с. (Studia philologica).

Русский язык в многоречном социокультурном пространстве / отв. ред. Б. М. Гаспаров, Н. А. Купина. Екатеринбург : Изд-во Урал. ун-та, 2014. 324 с.

Русский язык конца XX столетия (1985-1995) / отв. ред. Е. А. Земская. М. : Языки славянских культур, 1996. 480 с.

Русский язык сегодня. Вып. 2 / отв. ред. Л. П. Крысин. М. : Ин-т рус. яз. им. В. В. Виноградова РАН, 2003. 634 с.

Современный русский язык : Активные процессы на рубеже XX-XXI веков / отв. ред. Л. П. Крысин. М. : Языки славянских культур, 2008. 712 с.

\section{References}

Gasparov, B. M. \& Kupina, N. A. (Eds.). (2014). Russkij yazy'k v mnogorechnom sociokul'turnom prostranstve [The Russian Language in a Multilanguage Socio-cultural Space]. 324 p. Yekaterinburg, Izdatel'stvo Ural'skogo universiteta.

Kry'sin, L. P. (Ed.). (2003). Russkij yazy'k segodnya [The Russian Language Today]. (Iss. 2). 634 p. Moscow, Insitut russkogo yazy'ka imeni V. V. Vinogradova RAN.

Kry'sin, L. P. (Ed.). (2008). Sovremenny'j russkij yazy'k: Aktivny'e processy' na rubezhe $X X-X X I$ vekov [The Modern Russian Language: Current Processes at the Turn of the $21^{\text {st }}$ Century]. 712 p. Moscow, Yazy'ki slavyanskih kul'tur.

Kupina, N. A. (2015). Totalitarny'j yazy'k: Slovar' i rechevy'e reakcii. [A Totalitarian Language: Its Vocabulary and Speech Reactions]. (2 ${ }^{\text {nd }}$ ed.). 186 p. Yekaterinburg, Izdatel'stvo Ural'skogo universiteta.

Mokienko, V. M. \& Nikitina, T. G. (1998). Tolkovy'j slovar' yazy'ka Sovdepii [An Explanatory Dictionary of the Language of Sovdepia]. 704 p. Saint Petersburg, Folio-Press.

Ratmajr, R. (2013). Russkaya rech' $i$ ry'nok: Tradicii $i$ innovacii v delovom $i$ povsednevnom obshhenii [Russian Speech and Market: Traditions and Innovation 
in Business and Everyday Communication]. 456 p. Moscow, Yazy'ki slavyanskoj kul'tury'.

Vepreva, I. T. (2012). Yazy'kovaya refleksiya v postsovetskuyu e'pohu [Language Reflection during the Post-Soviet Era]. 380 p. Yekaterinburg, Izdatel'stvo Ural'skogo universiteta.

Zemskaya, E. A. (Ed.). (1996). Russkij yazy'k koncza XX stoletiya (1985-1995) [The Russian Language of the Late $20^{\text {th }}$ Century]. 480 p. Moscow, Yazy'ki slavyanskih kul'tur.

The article was submitted on 25.06.2015

Наталия Александровна Купина, Natalia Kupina, профессор, Уральский федеральный Professor, университет, Екатеринбург, Россия, Ural Federal University, Yekaterinburg, Russia, natalia_kupina@mail.ru 